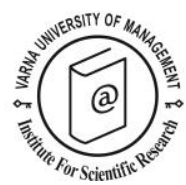

\title{
'You have to try being a role model' - Learning for sustainability among tourism entrepreneurs in a Swedish biosphere reserve
}

\author{
Fredrik Hoppstadius ${ }^{{ }^{*}}$ and Cecilia Möller ${ }^{2}$
}

Received: 18/12/2017 Accepted: 08/05/2018

\footnotetext{
1 Department of Geography, Media and Communication, Karlstad University, Karlstad, Sweden Karlstad University, Universitetsgatan 2, SE-651 88, Karlstad, Sweden. fredrik.hoppstadius@kau.se

2 Department of Geography, Media and Communication, Karlstad University, Karlstad, Sweden Karlstad University, Universitetsgatan 2, SE-651 88, Karlstad, Sweden. cecilia.moller@kau.se

* Corresponding author
}

\begin{abstract}
The pursuit for sustainability in biosphere reserve (BR) tourism entails the need not merely for tourism businesses to adapt to the changing environmental preferences of tourists but also for entrepreneurs to gain new knowledge about sustainability. Our study illustrates how place is central to grasp the processes of learning for sustainability. Drawing on qualitative interviews, we examine place-specific and social learning processes for sustainability among small-scale tourism entrepreneurs in a Swedish BR. The findings are discussed using an analytic framework, based on themes of place-specific learning emerging from the interviews. Learning for sustainability among tourism entrepreneurs entails an emphasis on both social and spatial processes. Our findings show how the small-scale tourism entrepreneurs engage in learning through their interactions with tourists at their tourism establishments, through networking with other tourism businesses and regional stakeholders, through engaging with local resources and cultural norms of the BR, and through their experiences and practices connected to their everyday lives and the private sphere.
\end{abstract}

(C) 2018 Varna University of Management. All rights reserved

Keywords: Sustainability; place; learning; tourism entrepreneurship; biosphere reserves (BRs)

Citation: Hoppstadius, F., C. Möller (2018) 'You have to try being a role model' - Learning for sustainability among tourism entrepreneurs in a Swedish biosphere reserve. European Journal of Tourism Research 20, pp. 28-45

\section{Introduction}

Tourism has become an important part of sustainability efforts in many biosphere reserves (BRs) (see Azcárate, 2010; Habibah et al., 2013; Hearne and Santos, 2005; Kala and Maikhuri, 2011; UNESCO, 2002). The BRs are founded, promoted, and sanctioned as learning sites for sustainable development by the United Nations Educational, Scientific and Cultural Organization (UNESCO) and its Man 
and the Biosphere programme (UNESCO, 1971, 1996). Previously, BRs were focused more on preservation and conservation, but after UNESCO's (1984) action plan, the aims of BRs became more diversified and included both economic and social development (Ishwaran, Persic, and Tri, 2008). In 2002, UNESCO initiated ecotourism development in BRs as a way to promote nature and community engagement and learning for sustainability (UNESCO, 2002).

Tourism in BRs is acknowledged as a method of providing paths for the development of smallscale and locally anchored nature tourism, with the ambition to minimise negative environmental effects (Ishwaran, Persic, and Tri, 2008). Borsdorf et al. (2014) argues that sustainability in BR development benefits from a place-specific approach that entails extensive stakeholder involvement and taking local conditions and geographical variations into account. Thus, promoting tourism in BRs is used as a tool for putting the aims of sustainability into practice, as BRs are meant to function as learning labs that combine conservation efforts with sustainable development (UNESCO, 1996). Yet, previous research points to that tourism's contribution to sustainability in BRs remains unclear (Buckley, 2012). Moreover, few studies have explored the learning processes for sustainable development in BR tourism. Learning for sustainability in general is described as social processes, aimed at creating new knowledge through information sharing, interactions, and joint sense-making (Leal-Rodríguez, Roldán, Leal, and Ortega-Gutiérrez, 2013).

In BR tourism, learning occurs through simultaneous production and consumption processes, based on the interactions between different stakeholders (e.g., tourists, entrepreneurs), and BR organisations (Backman, 2012; Hearne and Santos, 2005; Malena and Schultz, 2017; UNESCO, 2002). This means that research would benefit from focusing on place-specific processes in order to facilitate sustainability in BRs (Borsdorf et al., 2014). In addition, social processes of learning for sustainability, as proposed by LealRodrìguez et al. (2013) is needed to understand how tourism contributes to sustainability in BRs.

The purpose of this article is to explore placespecific and social learning processes for sustainability among small-scale tourism entrepreneurs in a biosphere reserve. Our case study covers small-scale tourism entrepreneurs committed to an ecotourism network project at the Lake Vänern Archipelago Biosphere Reserve in Sweden. In our analysis, we understand place-specifics of learning as also including spatial processes, influenced by Massey's (2005) understanding of place as relational, and paying attention to place-specific characteristics of the BRs. Stagl (2007) stated that learning processes of and for sustainability require empirical research that attempts to capture various place-specific processes and links between learning processes on different scales. Thus, learning processes are embedded in different local contexts when applying and putting the aims of sustainability into practice, while engaging and collaborating with a range of actors from the local to the international level (Hoppstadius and Dahlström, 2015).

Within the field of tourism studies, few studies have linked issues of learning for sustainability to the role of tourism entrepreneurs. Ogonowska and Torre (2013) claimed that the role of tourism supply in the emergence of new environmental norms entails that tourism producers and providers need to adapt to the changing environmental preferences of tourists.

We argue that there is a need to go beyond studies of adaptation and consider how tourism entrepreneurs engage in processes for sustainability, such as learning. In BRs, entrepreneurs are not merely expected to adapt to the aims of sustainable development but also become 'role models' through the ambition of BRs as 'test sites' for sustainability.

Previous studies show how small tourism business owners are driven by lifestyle factors, such as being able to create a livelihood in an attractive environment and engage in lifestyle activities or hobbies (Dewhurst and Thomas, 2003). Small firms are less likely to adopt environmental strategies and certifications 
because of a lack of administrative, financial, and human resources as well as time constraints (Sampaio, Thomas, and Font, 2012; R. Thomas, 2015). On the other hand, Dewhurst and Thomas (2003) claimed that small firms may show more commitment to sustainability issues because of their lifestyle orientation and local attachment.

\section{Case Study Area}

The BR concept was proposed as a means for creating international cooperation and collaboration regarding global environmental problems (UNESCO, 1971). The vision of the BR concept is to promote selected areas with a high conservation value as test sites for sustainability that function as an inspiration for other localities (UNESCO, 1984).

Our case is Lake Vänern Archipelago Biosphere Reserve in Sweden (see Figure 1).
The BR contains protected nature, including parts of Lake Vänern (the largest lake in Sweden and the third largest lake in Europe), and almost 60,000 people live in the mostly rural landscape of the BR. The main cities are Mariestad, Lidköping, and Götene. The BR comprises a national park, Natura 2000 sites, nature reserves, protected forest and fish habitats, protected shores, and areas of national interest for cultural heritage conservation (UNESCO, 2010).

Tourism development and entrepreneurship are integrated in the sustainability strategies of Lake Vänern Archipelago Biosphere Reserve (Malena and Schultz, 2017). Between 2009 and 2012 an ecotourism network project was coordinated by the BR office in Mariestad and aimed to expand opportunities for public transport, develop bike trails and walking trails, produce maps for the new bike and walking

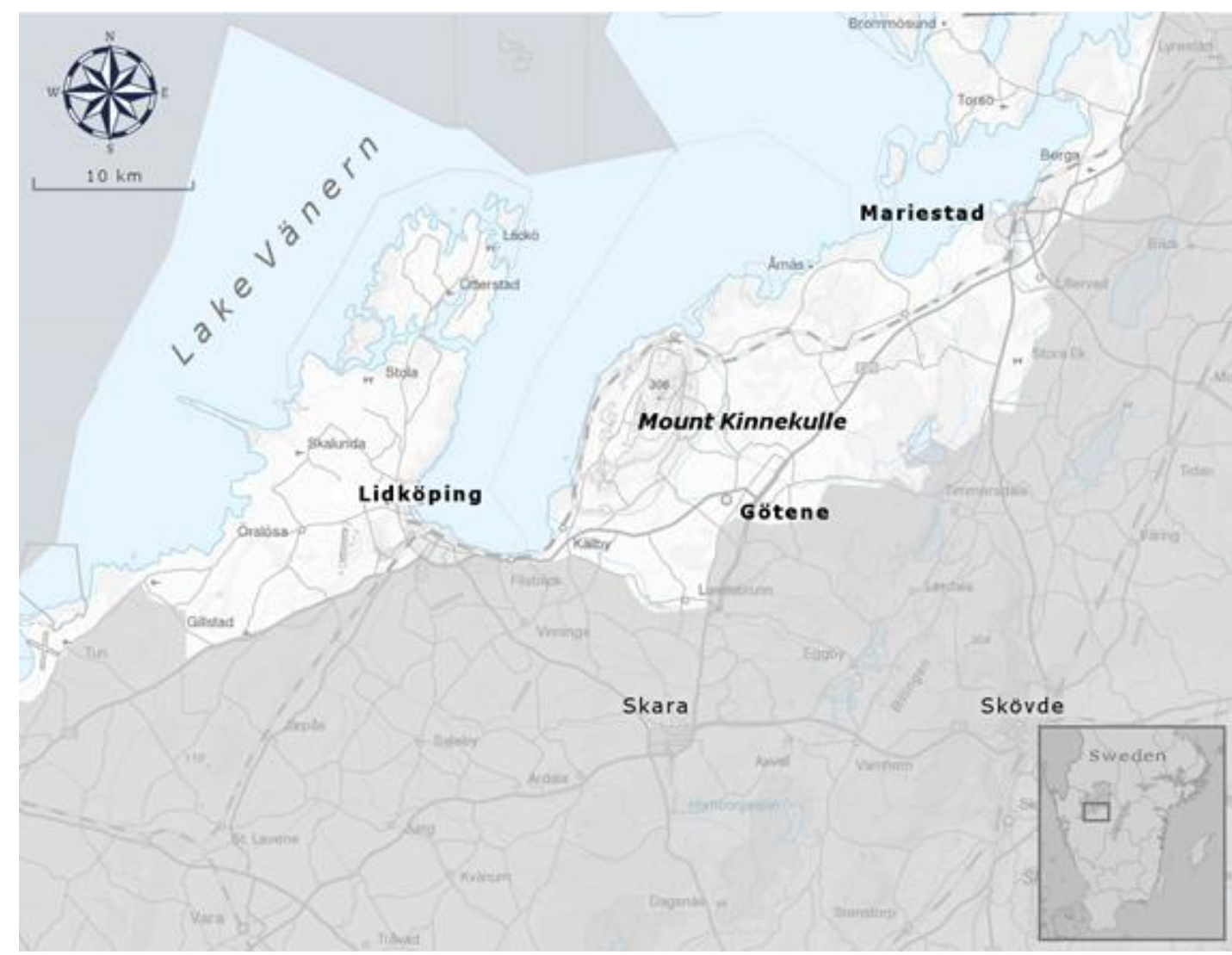

Figure 1. Map of the BR, showing the area, the cities, and the BRs location in Sweden. Courtesy of the Swedish Mapping, Cadastral and Land Registration Authority. Map created by Jan Alexandersson 
trails, develop new ecotourism products, and initiate joint marketing efforts aimed at promoting ecotourism in the BR (Backman, 2012). The premise of the project was that it is important for tourism producers in the BR to understand that tourism is a branch of industry that is largely unsustainable, yet tourism can be more sustainable in some cases with thorough planning, learning, and education and within certain subfields of tourism (e.g., ecotourism).

\section{Literature Review}

\section{Learning for Sustainability in BRs}

Researching learning for sustainability in BRs entails an understanding that sustainability is more than just an international agenda. Sustainability comprises on-going processes that remain difficult to define and achieve because of the constantly changing conditions that are necessary for sustainability (Spaargaren, 2011). Hence, learning becomes integral in the drive towards sustainability in BRs and as an important measure to stimulate sustainable environmental, economic, and socio-cultural development (UNESCO, 1996, 2015 , 2016). Learning in the context of sustainability occurs as a result of many processes (e.g., individual learning, cooperation, and interactions) between many different stakeholders, such as individuals, businesses, and decision makers (Hansmann, 2010). In tourism, learning related to sustainability involves collaborations and collective learning among stakeholders with the intention of creating a sustainable future for their tourism destination (Schianetz, Kavanagh, and Lockington, 2007).

Three main approaches to learning can be identified in the literature: processes of individual, social, and organisational learning. According to Stagl (2007), individual learning depends on the social networks and peers wherein new information and inspiration is provided. Thus, individual learning is concerned with how learning occurs and seems to require certain degrees of social interaction to develop and flourish. Social learning, as discussed by Keen, Brown, and Dyball (2005); Mesquita, Anand, and Brush (2008) focuses on the purpose of learning, occurs in interactions, and seems to be driven by a will to generate change. Further, social learning enables actors to take advantage of diversity perspectives (Sol, Beers, and Wals, 2013). The way actors take advantage of the different perspectives is by continuously producing and reproducing trust and commitment and reframing through the actions and interactions of individual actors (Sol et al., 2013). The third type of learning discussed in the literature is organisational learning, which is learning with clear objectives connected to the organisation. It focuses on the transfer of both explicit and tacit knowledge within the organisation (Crossan, Lane, and White, 1999).

Together, these approaches highlight the importance of social processes for learning for sustainability. However, these learning perspectives tend to be actor-centred, and rarely focused on the spatial processes that are central to sustainability and essential for the local negotiation of the global goals of sustainability.

\section{Learning and Place}

Leal-Rodríguez et al. (2013) defined learning as knowledge integration, information sharing, and collective sense-making. We build on this further by incorporating spatial processes into the concept. The spatial dimensions of learning for sustainability have previously been explored with a focus on different conditions (Picard, 2015), scales (Fernandez and Sanchez Rivero, 2009), innovation (Leach et al., 2012), and cooperation (Farrell and Twining-Ward, 2005), while little focus has been given to social processes, especially in a BR context (McCarthy, Whitelaw, Jongerden, and Craig, 2011). Schianetz et al. (2007) showed that the characteristics of interactions, opportunities for change, and the tourism destination where learning is occurring are dependent on placespecific conditions.

There is further knowledge to be gained by incorporating how learning occurs, what the purpose of learning is (e.g., increasing sustainability or increasing profitability), and how the objectives of organisations like BRs influence learning. Sustainability and learning involve spatial processes of interaction between actors on different geographical scales of society (de Kraker, Cörvers, Valkering, Hermans, and Rikers, 2013; 
'You have to try being a role model' - Learning for sustainability among tourism entrepreneurs in a Swedish biosphere reserve.

Nguyen, Bosch, and Maani, 2011). Other studies have emphasised the spatial processes as crucial in the ambitions to promote innovation and change in the work for sustainability. Nguyen et al. (2011) showed how learning laboratories can be used to gather local operators and stakeholders and to create a sense of togetherness in planning for the future and making decisions.

Place is a major geographical notion that remains contested through how various social relations, ideologies, and institutional structures are interlinked through practices that make places come into being (Paasi, 2002). In other words, place comprises the foundation, conditions, opportunities, and prerequisites in which, for example, BRs are given meaning. Place becomes relational and dependent on more than just our subjective understanding of place; places are continuously being created through interaction and negotiations, both at the Euclidian location and in our subjective minds (Massey, 2005).

The connections between place, sustainability, BRs, and learning lie in the local negotiation of global goals, such as sustainability, and how sustainability effect local BR tourism stakeholders through different social and spatial processes. In earlier work, Massey discussed two notions: 1) place-specific content being important for the understanding of how economic restructuring occurs in the sense that place affects opportunities, barriers, and characteristics of economic development (Massey, 1991) and 2) that the continuously negotiated conditions of places affect social structures and the outcomes of economic development (Massey, 1995). Using Massey's theories, we generate an understanding of the significance of 'the relational' in understanding sustainability.

Relational places are continuously being created through different interactions and negotiations, both at the location (the local BR) and in the minds of people operating in the BR. According to Massey, place is fluid and changing and is connected through the ambitions of stakeholders but also through the interactions among people. The where, how, and why of place can be understood as places being brought into existence when people assert meaning to it. The where of place consists of characteristics, such as the distance from the core, periphery, and its whereabouts in relation to other places (e.g., where learning is happening; (Peet, 1998). Place can provide an explanation of how something is (e.g., that the different features and preconditions of places affect their economic and social development possibilities; (Ek and Hultman, 2007), such as how learning is happening. Massey (2005) described the why of place as originating in the comprehension of place uniqueness through the continuous give and take of the here and now and the simultaneity of trajectories coming together (e.g., why learning is happening in certain ways).

\section{Tourism Entrepreneurship and Place-specific Learning for Sustainability}

The understanding of place as relational provides a theoretical platform for interpreting the actions and ideas of BR tourism entrepreneurs. The concept of place is deeply influenced and shaped by our actions, desires, and consumption, which are features that are prominent in tourism. Rakić and Chambers (2012) argued that the simultaneous processes of production and consumption of place in touristic places would benefit from being researched through the experiences of locals and tourists. Learning among the producers of tourism also provides opportunities for taking control of tourism management and development and empowers and motivates the producers (Regmi and Walter, 2016).

The tourism entrepreneurs in a destination do compete against each other, but the organisational structure and success of a destination benefits from being perceived as a network of interdependent collaborating stakeholders (Cooper, Scott, and Baggio, 2009). Further, the quality and tourism supply of a destination depend on stakeholders collaborating in networks (March and Wilkinson, 2009); Saarinen (2006) argued that the possibility for sustainability in tourism rests in the notion that tourism entrepreneurs sell a product whose quality is linked to their sustainability efforts. 
Few studies have related the issue of learning for sustainability to the role of tourism entrepreneurs. In a Russian context, Kask, Kull, and Orru (2016) found that producers' attitudes towards sustainable tourism are influenced to a large degree by personal background within sustainability ahead of international concepts and definitions of sustainability. Regmi and Walter (2016) focused on learning in businesses involved in community-based ecotourism, but there is a lack of studies that highlight learning processes within tourism initiatives in a European or 'Western' setting. Furthermore, Sampaio et al. (2012) stated that studies of what factors affect environmental engagement in small businesses have been neglected within tourism research. They found that day-to-day activities and experiences in nature among small firm owners (e.g., growing one's own vegetables) helps fulfil personal goals, which is typical for more lifestyle-oriented businesses.

The motives for starting small tourism businesses are also perceived to be different. The tourism entrepreneurs are described as being 'forced' or 'coincidental', reflecting a certain family situation, such as a desire to stay and live in the countryside or engage in natureor culture-related activities (Lundberg, Fredman, and Wall-Reinius, 2014). In other words, the motives for small-scale tourism entrepreneurship are often connected to place.

\section{Implications of the literature review}

One of the main objectives of BRs is to develop sustainability, and tourism development has become a prioritised and integrated part of these sustainability efforts (UNESCO, 2016). Our literature review discusses learning for sustainability in BRs by situating learning in a BR context with three main approaches to learning that together make up social processes of learning for sustainability.

The contribution of tourism to sustainability is often poorly understood, and a focus on placespecific processes, as proposed by Borsdorf et al. (2014), is required. We put emphasis on the connections between learning and place, spatial processes of learning and the incorporation of a relational understanding of place as suggested by Massey (1991; 1995;
2005). This anchors our article in place-specific learning processes, and provides an analytical tool for analysing how the informants relate to learning for sustainability in a BR.

Our literature review also highlights how learning for sustainability among small-scale entrepreneurs may be related to place-specific conditions and life-style motives for entrepreneurship, providing both opportunities and challenges for engaging in BR tourism.

\section{Method}

The perspectives of nine local tourism entrepreneurs comprise the empirical foundation of our study. The informants were chosen on the criteria that they operated a tourism business within the BR and that they had participated in the ecotourism network project between 2009 and 2012 . There are 20 tourism entrepreneurs of the former ecotourism network that fulfil the selection criteria, and all 20 tourism entrepreneurs were contacted via email. Out of the 20 entrepreneurs, six did not want to participate in the research, while three others were currently inactive, and two informants did not respond at all.

The nine informants that wanted to participate represent diverse parts of the tourism supply at the locality (e.g., agricultural tourism, heritage tourism, large-scale accommodation, hostel, café business, culinary tourism, and activity tours) (see table 1). The informants were given pseudonyms accompanied by a classification of their tourism business to delete identifying information to protect the informants from harm or embarrassment while still being able to stand for a group of people with specific traits (cf D. Smith, 1987).

The nine informants had all participated in the ecotourism network and were considered to possess experience in the field of study. Polkinghorne (2005) emphasised the value of characteristic life experience within the scope of the study as important for purposeful selection of informants. The informants represent a specialised group, which is difficult to generalise. The group of informants in the article is similar to the specialised population in the work by Regmi and Walter (2016). However, our ambition is not to generalise from our findings but to highlight the complex nature 
'You have to try being a role model' - Learning for sustainability among tourism entrepreneurs in a Swedish biosphere reserve.

Table 1. Description of informants

\begin{tabular}{llll}
\hline Informant & Age & Gender & Type of tourism business \\
\hline Mark & $50 \mathrm{~s}$ & Man & Hostel \\
Charles & $40 \mathrm{~s}$ & Man & Heritage tourism \\
Johanna & $40 \mathrm{~s}$ & Woman & Activity tours \\
Ben & $40 \mathrm{~s}$ & Man & Large-scale accommodation \\
Jessica & $50 \mathrm{~s}$ & Woman & Café and handicraft \\
Anne & $40 \mathrm{~s}$ & Woman & Culinary tourism \\
Steve & $50 \mathrm{~s}$ & Man & Agricultural tourism \\
Sophie & $50 \mathrm{~s}$ & Woman & Culinary tourism \\
Margaret & $50 \mathrm{~s}$ & Woman & Agricultural tourism \\
\hline
\end{tabular}

and explore learning for sustainability among small-scale tourism entrepreneurs in a BR in an interpretative manner.

In interpretative research, it is essential to get close to the informants, as this allows for an understanding of the complexity within which individuals operate (Denzin and Lincoln, 2008; Phillimore and Goodson, 2004). The use of this approach allows the researchers to produce data with an inside view of how tourism entrepreneurs interpret sustainability in relation to learning processes in work, everyday life, and place-specific processes.

To gain a deeper understanding of the informants' stories, the interpretative approach of semi-structured interviews was used to collect material for the study (K. Thomas, 2004). The semi-structured interviews ranged from one hour to two hours. The main themes of the study (learning, sustainability, entrepreneurship, and the BR) were introduced to the informants. Then, the informants were asked the same questions with follow-up questions for clarification depending on the responses. This gives the informants leeway to explain how their experiences (of sustainability) relate to their everyday lives (J. K. Smith, 1983).

Themes and examples of follow-up questions drawn from the literature review:

1. Learning - How do you learn about sustainability?

2. Sustainability - What is the significance of sustainability and environmental issues for your tourism business?

3. Entrepreneurship - How does learning for sustainability affect the development of your tourism business?
4. The $B R-$ What is the significance of being part of a BR for the development of your tourism business?

\section{Creating an Analytical Framework}

A framework should spring from the research design. It helps researchers make sense of and interpret the material through theoretical themes and empirical concepts (Morrow, 2005). The purpose of our framework is to provide a way to make sense of the narratives of our informants in the context of our exploration of place-specific learning for sustainability in a BR.

The first stage of creating the framework was developed after a pilot study in 2014. The pilot study consisted of three interviews with informants from the former ecotourism network and was aimed at exploring how well our themes and questions worked in the field. The pilot study resulted in a few follow-up questions being added to the interview guide. Field notes were produced, parallel to the information gathered during interviews. The field notes also include material from the interviews and from discussion among the researchers. Creating the analytical framework consisted of compiling the interview notes and preparing the material for analysis. Further, creating the framework included searching for 'narratives', which Riessman (2008) defined as stored ways of knowing and fundamental ways humans organise their understanding of the world. We analysed the findings using thematic analysis, inspired by Braun and Clarke (2006), which comprised looking for themes within a framework, generating initial codes, reviewing potential themes, and defining and naming the themes. 
In the pilot study, we found that the informants were learning sustainability through social processes and interactions with other stakeholders. However, the analysis also revealed the importance of place and how the informants related to their surroundings in their learning processes. Three of the main themes that emerged through our analysis of the first two interviews were reflected in the theoretical background material we had chosen. We could identify social learning in social networks and individual learning driven by incentives to generate change and organisational learning.

At this stage, the incorporation of relational place provided insight into the place-specific segmentation connected to learning. Utilising Braun and Clarke (2006) thematic analysis, we generated three main themes after generating initial codes. These were 'learning through encounters in tourism establishments', 'learning as interaction with local and regional stakeholders in the BR', and 'local learning in the BR' (Figure 2). Moreover, a fourth dimension emerged from the material, which related to how the informants balanced and incorporated their everyday lives in relation to their tourism business. After the pilot study, we added a fourth theme, drawn from our empirical findings, to our framework to capture the dimension 'learning in relation to everyday life'. This theme gave depth to the distinction between the private and public spheres and how these aspects are intermingled in the relational learning processes of small-scale tourism entrepreneurs in BRs.

Applying the framework facilitates discovering and understanding the role that place-specific learning plays in advancing sustainability in a BR by highlighting how tourism entrepreneurs relate to their surroundings. Analysing the findings through the themes of the framework allowed us to summarise several hours of conversations to create a manageable format that can be easily understood by readers of this paper. Each of the four themes of the framework has several subthemes that were inductively drawn from the material (Figure 2).

\section{Empirical Findings: Relating to Their Surroundings}

The empirical findings indicate that social and place-specific processes of learning for sustainability, among our informants, influence how they relate to their surroundings in different ways (Figure 2). The themes represent how the informants approach and understand learning in different place-specific conditions, and the subthemes represent place-

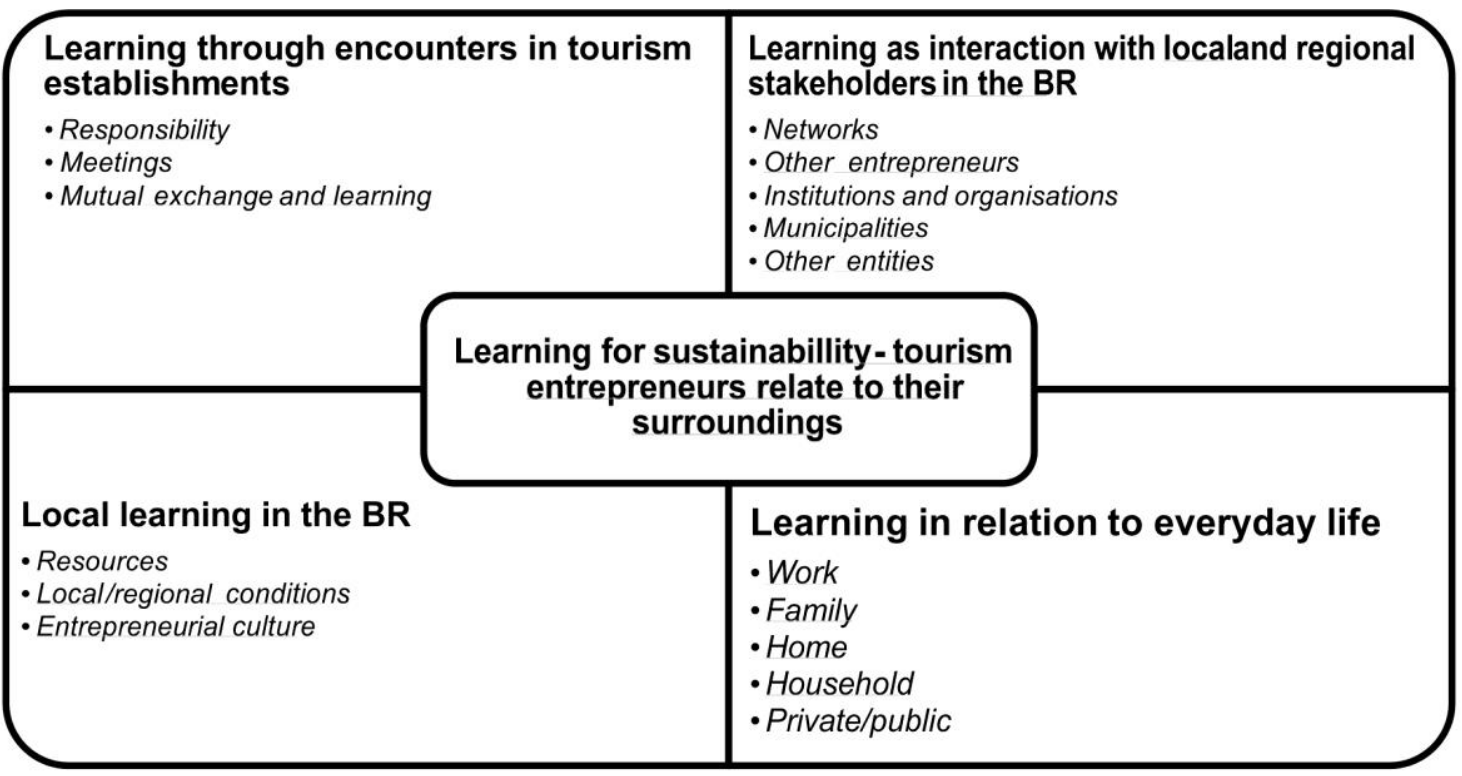

Figure 2. Relating to their surroundings: How learning for sustainability is interpreted among smallscale tourism entrepreneurs in a BR 
'You have to try being a role model' - Learning for sustainability among tourism entrepreneurs in a Swedish biosphere reserve.

specific expressions and tensions within each theme. Each theme is presented under the following four sections. The subthemes of each theme are in italics and exemplified with quotes. These subcategories help frame the findings and are presented below each theme in the application of the framework.

\section{Learning Through Encounters in Tourism Establishments}

Learning sustainability through interactions with tourists in the tourism establishments of the informants included being a role model and taking responsibility for the mutual exchange that occurs during their interactions. The informants saw themselves as ambassadors for sustainability. Showing others that it is possible to operate a tourism company environmentally sustainably was important for all the informants. Sustainability becomes interwoven with place as the informants strive to show how they, and ultimately the BR, are working to become more sustainable.

In most cases, the informants repeatedly came back to learning connected to the place of their tourism establishment and how this learning was used to further their sustainability efforts. The informants talked about the opportunities to learn from new people, while being able to communicate their ideological beliefs regarding the environment and sustainability. The informants wanted to generate change, and they had the will to implement change. Mark (hostel) said: 'Sometimes sustainability is hard to convey. We try to listen to what people [the tourists and other entrepreneurs] say... But, we also need to keep trying to become better at it. You [the tourism entrepreneur in the BR] have to try being a role model, inform people how you run your business, and do better showcasing'. The learning outcome for the informants was that they had to continuously keep working on becoming more sustainable to live up to their own expectations and those of the tourists that visit them.

The informants did not, for the most part, emphasise what they specifically learnt from each encounter with the tourists. Rather, learning seemed synonymous with personal growth and the associated improvement in their sustainability efforts related to their work, for example, obtaining tips from tourists on issues of sustainability in general and in tourism more specifically. Being able to show the tourists the 'beauty of the region' gave the informants the opportunity to assess the importance of nature conservation relative to that of economic development. Charles (heritage tourism) said: 'Nature and sustainability... it means a lot for us. We incorporate it in our trips... It's about viewing the BR from the "outside"! Changing perspectives! Drinking the water, listening to silence, experiencing Lake Vänern. The biosphere reserve is air, water, people... everything! We want to show people the water'? The learning outcome was that the informant connected their own sustainability efforts as interlinked with the BR and the surrounding environment.

The informants emphasised meetings with tourists as being crucial to their sustainability objectives. They used the meetings to create an arena to share knowledge about the region and about nature. This means that the informants utilised the meetings with tourists to talk about their interests (e.g., tourism, the environment and sustainability) to share the knowledge they have and to learn new things from the tourists, such as current trends in sustainability, ways to become more efficient, aspects of sustainability that are important for tourists, and how to better convey their sustainability efforts.

Charles (heritage tourism) said: 'Many young people have an interest in history and nature... We teach in the field by interacting with them... How to experience and understand nature'. Sharing knowledge about nature, which was often considered synonymous with sustainability, was central in interactions with tourists.

Learning in relation to tourists was described as occurring through mutual exchange. The informants valued their interactions with the tourists, as it helped them experience the nature and beauty of the BR anew. Johanna (activity tours) said: 'It's exciting taking tourists out in nature... going on tours in nature. We get an opportunity to show what we love [nature]... [and] You get to see it [the BR] through them'. 
The informant discussed with tourists how tourism in many ways is unsustainable and learnt that more tourists want to travel and experience things that are environmentally sustainable. The informants talked about how interactions with tourists made them feel fortunate about living in such beautiful surroundings, in a region with strong entrepreneurial and cultural spirit. Positive connotations of learning and sustainability were attributed to back-to-nature ideals and perceptions of the 'rural idyll'. This is something that the informants felt was easily lost in the entrepreneurial struggle. Nonetheless, interacting with the tourists gave the entrepreneurs a chance to experience the BR through their shared experiences at the locality. The businesses of our informants proved to be important prerequisites and places to engage in learning with their customers.

Learning though encounters in tourism establishments provides the basis for how our informants learn about sustainability. The interactions between our informants and tourists were often the first things they talked about, and during our interviews, they often came to the notion of the tourism business as a place in which interactions were enabled and built upon.

Learning as Interaction with Local and Regional Actors in the $B R$

Sharing knowledge and learning from the surrounding actors (e.g., businesses, tourism organisations, non-tourism organisations, sports clubs, schools, and municipalities) was often emphasised as crucial and necessary for continued work towards sustainability. The informants learnt innovative approaches to incorporate sustainability in their businesses, which strategies that had worked or not worked for other businesses, and the importance of cooperation. The informants talked about learning as something that occurs through social networks and work as inspiration and a sense of fellowship with peers.

The learning outcomes were that the informants could pick up innovative ideas and learn lessons from others while trying to develop their businesses sustainably in the BR. The promotion of learning occurred through sharing and collaborating while exchanging certain specific knowledge (e.g., horticulture, carpentry, service-mindedness, marketing, etc.) between the tourism businesses. According to the informants, this networking strengthened their will to develop sustainably and made them feel connected to something bigger than themselves.

The tourism businesses did not stress a sense of competition against each other, but the informants felt that they could deliver a better overall tourism product when collaborating. Together, the businesses could make sense of sustainability processes by sharing and learning from each other. Mark (hostel) said: 'We are collaborating with other hostels. One network for accommodation, another one for hostels. The important thing [about sustainability] is to strike a balance and cooperate. Particularly concerning environmental issues in everyday life, but also regarding history and heritage'. The learning outcome for being a part of these different networks was a broadening of what new knowledge on sustainability exists to incorporate into one's own business. The networking undertaken by the informants put them in contact with other entrepreneurs in the region.

The encounters with other entrepreneurs were not always positive and sometimes resulted in irritation and annoyance. However, the informants still claimed that they benefited from the negative interactions and often used their gained experience in ascertaining their own understanding of sustainability, business objectives, and ideological standpoints. Sustainability was interpreted as a will to go through with changes, and some tourism entrepreneurs understood differences in sustainability undertakings as abilities connected to economic means, while others implied that is was connected to levels of ambition. In other words, growth and innovation were sometimes considered opposed to the small-scale and ideologically driven entrepreneurship prevalent in the BR. Ben (large-scale accommodation) said: 'The focus on environment [among tourism entrepreneurs in the BR] affects us a lot... There are a lot of very small businesses in the biosphere reserve that are in it [tourism business] as a "hobby". 
'You have to try being a role model' - Learning for sustainability among tourism entrepreneurs in a Swedish biosphere reserve.

We want to collaborate with businesses that try to make a living from tourism'. This informant was annoyed with the lack of concern among other entrepreneurs within the BR institutions and organisations regarding economic development.

Three other informants, in contrast, showed their gratitude for the opportunity to be a part of institutions and organisations. The informants talked about a notion of togetherness that provided them with the tools necessary to improve on their sustainability attempts. Showing the importance of place as something unifying and as creating the prerequisite for learning, Jessica (café and handicraft) said: 'It is so easy to forget about us here "in the countryside" ... That is why it's important that we [tourism businesses in the BR] pull together in the same direction... then we can find out what works... what's sustainable'. The informant was emphasising how feeling connected to other tourism businesses and other businesses in the region gave a sense of direction in terms of sustainability. The outcome of the interactions was an opportunity to learn from the successes and failures of others in the BR.

The need for the sharing of knowledge was prominent in the answers of the informants. Anne (culinary tourism) talked about the importance of having organised interactions: 'Spreading information in our networks is crucial. Many [other tourism businesses] know things we haven't learned yet... they might know tricks for developing business...or how to be more engaged in environmental issues'. By acknowledging that sharing of information was important, the informants reminded themselves to engage more in such behaviour.

Learning as interactions with local and regional stakeholders in the BR created opportunities for insight and introspection for our informants, and the place-specific interactions and networking of our informants' enabled learning with other entrepreneurs and businesses. The social processes of learning created opportunities for our informants to engage with other like-minded and sometimes very different stakeholders. In addition, the spatial aspects of place-specific conditions in a BR provided prospects of connecting their actions with the ambitions of others.

\section{Local learning in the $B R$}

Local learning in the BR could be seen in the learning among our informants as they discussed the effects and significance of operating in a BR and what this meant for them. The BR context in which the informants are active in many ways functions as a loosely tied together organisation that aims at becoming increasingly sustainable. The informants discussed learning outcomes related to the local $B R$ in ways that both focused on explicit sharing of knowledge and information (e.g., learning about sustainability through information and projects in the local $\mathrm{BR}$ ) and on tacit knowledge gained from interacting with $B R$ officials and other businesses engaged in the local BR (e.g., how to purvey the sustainability attempts of their business and how different BR projects could help the informants in their endeavours).

The importance of the BR office was discussed by all informants. Many expressed a frustration over the lack of organisation of aspects and conditions that they felt they needed. As a result, the informants wanted more opportunity to develop a better-functioning entrepreneurial culture and more recourses to undertake ecoinnovations.

Learning in the local BR was deeply connected to different forms of resources for the informants: 1) regarding what kind of environmental focus there is among people in the region and 2) the perceived quality mark of supranational organisations, such as UNESCO. Regarding the first item, Anne (culinary tourism): 'There's a certain kind of people that live here [in the BR]. The surroundings are so nice that it changes you... It [the BR] makes people think more about the environment'. Indicating that the BR attracted, affected, and helped build people as sustainability recourses. Concerning the second statement, Steve (agricultural tourism) said: 'If no one presses the businesses to... for instance... hand in environmental plans... then nothing's going to happen. We don't have any regular meetings with the biosphere office anymore.' The learning outcome for the informant was that the 
quality mark of the BR helped people try harder to reach their individual sustainability goals, and that the informant wanted more help from the BR. Another informant discussed the prerequisites of the $\mathrm{BR}$ 'Is it possible to get support [regarding tourism and sustainability]? No! But there's opportunity to discuss getting support' (Jessica, café and handicraft). The learning outcome was that the informant would not be given a pre-made or universal solution to certain problems; instead they would have to actively engage and participate in solving problems with assistance from the BR.

We found that the informants in our study relied both on their own previous experience and on the BR to provide reliability and trustworthiness in how to become more sustainable. One example of this is that the informants stressed the need for learning about environmental sensitivities and practices for sustainability. Learning practical ways to become more environmentally sustainable was discussed as being difficult due to obstacles connected to not knowing enough about sustainability. Often, when the informants discussed obstacles, they tended to clump together many negative aspects of their day-to-day endeavours, and often expressed disappointment towards the prerequisites of the $\mathrm{BR}$.

The informants became more negative when discussing entrepreneurial culture in a BR context compared with when discussing the same thing regarding collaboration with other local and regional actors. Many felt that the entrepreneurial culture provided by the BR office in different projects was poorly developed, and many had hoped that the BR office would provide a better platform for interaction. Mark (hostel) said: 'We want more meetings [to discuss problems and solutions regarding sustainability] with other tourism businesses'.

\section{Learning in Relation to Everyday Life}

The informants in the study are small-scale entrepreneurs operating small tourism businesses with close connections between their entrepreneurial ventures and their daily lives. This means that the informants were learning sustainability while balancing work, family, and home in both the public and private spheres. The learning outcome was a two-way process: 1) the informants' lives outside of their businesses affected their sustainability efforts as much as interactions through their businesses, and 2) their private sphere also restricted learning ambitions.

The way in which the informants discussed input from, and the balancing act of, entrepreneurship in daily life, implies that it is a key factor to consider. When being asked about sustainability and its significance in their lives, some informants highlighted soft and nurturing ideals, while others emphasised implementing objective and measurable technical improvements. Jessica (café and handicraft) wanted to convey that she felt that sustainability was brought about through changes in consumption and living and that her everyday life and entrepreneurship were interlinked: 'I think there is value in someone trying to live more sustainably, showing that it's possible to make do with less and live more naturally'. The way she lived privately influenced how she acted and learnt publicly as a small-scale tourism entrepreneur.

Ben (large-scale accommodation) took a different approach where he stressed the importance of technical innovation and effectiveness and that sustainability entailed a permanent quest to become more efficient both as an individual and through business ventures: 'Why don't we have charging stations for caravans? We need new technology and innovation to become greener'. Ben saw learning in his business as being influenced by his personal interpretation of sustainability and as being connected to the BR and notions of progressing sustainability.

Operating a tourism business in the BR entailed merging work with other aspects of one's life. Sophie (culinary tourism) told us about some of the benefits that came from including her family in the small-scale tourism business when asked about influences and happenings that the informant connected to learning and sustainability: 'I've learned a lot about sustainability from my daughter. She's studying at university'! The informant did not specify any one particular thing that she had learnt from her daughter, rather her relation to 
'You have to try being a role model' - Learning for sustainability among tourism entrepreneurs in a Swedish biosphere reserve.

her daughter was the crucial point, as it gave her access to additional information and knowledge connected to sustainability. Sophie (culinary tourism) stated that 'the business and my family are the same thing' when asked if her family members were involved with the tourism business.

It appears that the support and involvement of family members gave many of our informants confidence in their abilities and their sustainability efforts. Anne (culinary tourism) said: 'I think a lot of people thought we weren't going to make it. But we enjoy the work and we're good at cooking ecological food... and our hubbies help out too'. The informant claimed that she and her business partners' positions as women with little to no previous experience of small business management in the service sector made others doubt their commitment and likelihood of success. However, with help from their families, they managed to survive and expand their tourism businesses.

The close connection between work and family meant that issues relating to the informants' households became interlinked with their businesses. The informants wanted to live rurally, while engaging in different activities connected to the BR. Their lifestyle choices and their tourism businesses were directly connected to their family lives. Mark (hostel) said: 'We want to live here in the hostel; it feels more sustainable... Having someone else pay for our living'. Margaret (agricultural tourism) used her tourism business to provide food for the off-season, stating that tourism entrepreneurship 'is very seasonal and involves a lot of unpaid effort, but nowadays I grow my own food, so we make do'. These small but imperative efforts anchored the informants as role models for sustainability.

The findings derived from the analysis of the theme of learning in relation to everyday life differed slightly from the other themes. These moments when the informants discussed everyday life and family in connection to sustainability were often more personal. As a result, learning for sustainability that is connected to this theme appears deeply rooted in how the informants see themselves and what types of future goals and ambitions they have for themselves and their loved ones.

\section{Discussion}

The empirical findings have shown how smallscale tourism entrepreneurs in a Swedish biosphere reserve engage in social and placespecific processes of learning for sustainability. The informants put emphasis on different social, environmental and economic dimensions of sustainability in their learning processes. The informants tended to focus on environmental aspects of sustainability when contemplating and talking about place and the BR. However, learning processes for sustainability are inherently embedded in social settings of the BR, including engaging in learning though professional networks, in encounters with tourists, as well as learning for sustainability in relation to everyday life.

\section{Learning Through Tourism Encounters}

Overall the informants wanted to generate sustainable change by showing commitment in their BR businesses and their encounters with tourists. This is similar to the discussion by Keen et al. (2005) when arguing that this type of learning, social learning, is driven by hopes to generate change. Furthermore, we could see that the informants' meetings with tourists assisted greatly in fulfilling this aspect of learning for sustainability. The tourism establishments (restaurants, shops, accommodations, tours in nature and on Lake Vänern) are all places where the entrepreneurs meet and interact with tourists, talk about sustainability, and show the tourists how they (the entrepreneurs) chose to live as parts of the $\mathrm{BR}$. Thus, the BR becomes a place that is constantly created and negotiated in the encounter between the entrepreneurs and tourists.

Mesquita et al. (2008) argued that the interaction (provided by the tourism exchange) gives actors an arena in which to influence and share knowledge. Our informants relayed a desire to utilise the arena provided to them through their interactions with tourists to discuss and learn about nature, the environment, and the BR. In these discussions, the informants often deliberated on the unsustainability of tourism and connected this notion to the fragility of their products. 
Learning as interactions with other actors

Our informants talked about learning as something that occurs in social networks, similar to the findings of Stagl (2007). In the findings, the informants described their will to implement change as an important driver for sustainability, as previously expressed by Mesquita et al. (2008). However, in addition, the informants described their businesses and the BR as something fluid and changing, connected to learning for sustainability through their own ambitions and through interactions with others. Inspired by Massey (2005), place can be defined as relational and as continuously being (re)created and (re)negotiated through different interactions between BR stakeholders.

As shown by Sol et al. (2013), the production and reproduction of commitment, trust, and reframing generates learning through the actions and interactions of various individual actors. In our study, the informants were motivated through the interactions they experienced in different networks in the BR. This finding demonstrates that place matters, as different preconditions (e.g., in another place or another BR or non-BR) would affect how the informants view their development opportunities and objectives. The place and our informants way of discussing place (when discussing sustainability and interactions with other actors in the BR) can be understood through the discussions of Ek and Hultman (2007), where different features and preconditions of places affect their economic and social development possibilities. In our case, learning for sustainability occurred through sharing and collaborating certain specific knowledge in different networks. Sustainability learning, as described by Hansmann (2010), benefits from being understood as a multi-level concept where both individual learning processes and collective learning processes are interacting. We found that a perceived notion of togetherness provides the informants with the tools necessary to learn sustainability.

\section{Local learning in the $B R$}

The informants connected their learning, ambitions, and interpretation of sustainability to larger international discussions of sustainability (e.g., connected to UNESCO's framework and ambitions associated with what a BR is intended to achieve). The BR represents both who and what they are, but also what they could be. Both the meaning and disconnection are tied to the place-specific conditions for the informants. This can be exemplified with the expressed importance of the BR among the informants, while they also revealed a frustration over the lack of organisation and management from the BR office. The importance of lacking aspects in the BR can be understood through Massey's (2005) discussions on unestablished relations, exclusions, and a lack of meetings, as often playing a vital role in the (learning) conditions of places. Massey stated that non-relations and non-meetings matter as much as actual relations and meetings.

Place is not only connected to successful and positive processes but is also connected and influenced by processes that are deficient. In our case, this manifested in how the informants felt that they did not get enough support from the BR officials and that this made them feel that they were lacking the opportunity to engage with projects and ventures initiated by others. This lack, unestablished relation, or perceived missed opportunity or exchange affects the informants not only in a negative way but also in a sense that enables a drive for problem solving and finding the best ways to utilise place-specific conditions in the BR. That which might be 'lacking' in a place is also part of that which generates place-specific conditions and opportunities, just in a different way. This finding shows that both the meaning and disconnection were related to the placespecific conditions for the informants. This reveals that, even though the informants knew that they themselves had to be active in the $\mathrm{BR}$, they still wanted the BR to arrange more opportunities for them to interact with other businesses.

\section{Learning in relation to everyday life}

Finally, when taking everyday life into consideration, the family situation of informants becomes important, as well as their wishes to stay and live rurally to engage in nature and cultural activities (Lundberg et al., 2014; Möller, 2009). In our study, we saw a strong 
'You have to try being a role model' - Learning for sustainability among tourism entrepreneurs in a Swedish biosphere reserve.

connection between family and business among the informants.

Learning for sustainability in relation to everyday life among our informants indicates that social aspects and spatial aspects of learning and sustainability are intricate and complex processes that contain many dimensions relating to both public and private dimensions that shape how the informants understand and learn sustainability in a BR. The notion of and importance of place become even more crucial to incorporate into learning for sustainability in the BR. Social and spatial processes of learning for sustainability seem to connect dimensions relating to both the public and private sphere, which impacted the way in which the informants learn sustainability in the BR.

Massey (2005) argued that place uniqueness comes through the continuous give and take of the here and now as well as the simultaneity of trajectories coming together. We found that the connection to everyday life conveyed that the trajectories that influence our informants are connected not only to their tourism businesses but also to their families and the way that the informants have chosen to live their lives.

When our informants discussed how learning for sustainability impacted their businesses, they all connected their professional endeavours with their private lives. The characteristics of the informants and their families influence their views and opinions on sustainability, the BR and ultimately how they choose to run their businesses. Learning in relation to everyday life shows that social aspects and spatial aspects of learning and sustainability are intricate and complex processes that contain many dimensions relating to both public and private dimensions that shape how the informants understand and learn sustainability in a BR.

\section{Conclusion}

The purpose of this article has been to explore place-specific and social learning processes for sustainability among small-scale tourism entrepreneurs in a biosphere reserve. We asked our informants questions about placespecific and social learning processes for sustainability. The empirical findings are discussed using an analytic framework, based on themes of place-specific learning. Our study gives examples on how place, social processes and spatial processes of learning for sustainability show how tourism businesses adapt to the changing environmental preferences of tourists but also how entrepreneurs gain new knowledge about sustainability.

The findings show how the small-scale tourism entrepreneurs of Lake Vänern Archipelago Biosphere Reserve engage in learning for sustainability through their encounters with tourists at their tourism establishments, through interactions and networking with other tourism businesses and regional stakeholders in the $\mathrm{BR}$, and through engaging with local $\mathrm{BR}$ resources and cultural norms, and via their practices and experiences connected to their everyday lives and private spheres. The article underlines place-specific conditions connected to the BR and the integration of work with daily life as crucial in learning how to navigate their on-going sustainability endeavours.

In most cases, the informants did not make a distinction between their work lives and daily lives and often highlighted public and private aspects of learning connected to sustainability and tourism entrepreneurship. Future research could analyse the public and private dimensions of learning further (e.g., how gender in relation to place-specific learning for sustainability affects tourism entrepreneurs and their endeavours). Furthermore, we found that interactions with tourists seemed to have significance for the informants' work on sustainability. Future research could look qualitatively at BR tourism from the perspective of tourists (e.g., how tourists interpret and coproduce sustainability).

\section{Acknowledgements}

This research was made possible with funding from The Swedish Society of Anthropology and Geography (SSAG) under SSAG fund, 2015. We thank our colleagues from the Department of Geography, Media and Communication and the Region Building Research School at Karlstad University who greatly assisted the research. We would like to give special thanks 
to Thomas Blom and Lars Aronsson for their comments on the article. Advice given by Gillian Rose and Shova Thapa Karki has been a great help in framing the research and methods used. We are also immensely grateful to Margareta Dahlström, Louise Robertsson, Thomas Torbjörnsson and Mats Nilsson for their comments on earlier versions of the manuscript.

\section{References}

Azcárate, M. C. (2010). Contentious hotspots: Ecotourism and the restructuring of place at the Biosphere Reserve Ria Celestun (Yucatan, Mexico). Tourist Studies, 10(2), 99-116.

Backman, C. (2012). Projekt Ekoturistdestination Vänerskärgården med Kinnekulle. Lake Vänern Archipelago Biosphere Reserve. URL: http://media. vanerkulle.org/2013/09/2012_3-Slutra pport-ekoturismdestination.pdf (Accessed on 08.06.2014)

Borsdorf, F. F., Pelenc, J., Reutz-Hornsteiner, B., Tourneau, F. M. L., Velut, S., and Coy, M. (2014). The contribution of biosphere reserves to regional sustainability: an institutional approach. International Journal of Sustainable Society, 6(1), 60-81.

Braun, V., and Clarke, V. (2006). Using Thematic Analysis in Psychology. Qualitative Research in Psychology, 3(2), 77-101.

Buckley, R. (2012). Sustainable Tourism: Research and Reality. Annals of Tourism Research, 39(2), 528-546.

Cooper, C., Scott, N., and Baggio, R. (2009). Network position and perceptions of destination stakeholder importance. An International Journal of Tourism and Hospitality Research, 20(1), 33-45.

Crossan, M. M., Lane, H. W., and White, R. E. (1999). An organizational learning framework: From intuition to institution. Academy of management review, 24(3), 522-537.

de Kraker, J., Cörvers, R., Valkering, P., Hermans, M., and Rikers, J. (2013). Learning for sustainable regional development: towards learning networks 2.0? Journal of Cleaner Production, 49, 114122.
Denzin, N. K., and Lincoln, Y. S. (2008). The discipline and practice of qualitative research. In N. K. Denzin and Y. S. Lincoln (Eds.) (2008), Strategies of qualitative inquiry (3 ed). Los Angeles, CA: SAGE Publications Inc, 1-44.

Dewhurst, H., and Thomas, R. (2003). Encouraging sustainable business practices in a non-regulatory environment: A case study of small tourism firms in a UK national park. Journal of Sustainable Tourism, 11(5), 383-403.

Ek, R., and Hultman, J. (2007). Produktgörande av platser. In R. Ek and J. Hultman (Eds.) (2007), Plats som produkt - kommersialisering och paketering. Lund: Studentlitteratur AB, 13-36.

Farrell, B., and Twining-Ward, L. (2005). Seven steps towards sustainability: Tourism in the context of new knowledge. Journal of Sustainable Tourism, 13(2), 109-122.

Fernandez, J. I. P., and Sanchez Rivero, M. (2009). Measuring tourism sustainability: proposal for a composite index. Tourism Economics, 15(2), 277-296. doi:10.5367 1000000009788254377

Habibah, A., Mushrifah, I., Hamzah, J., Er, A. C., Buang, A., Toriman, M. E., ... Zaimah, R. (2013). Place-Making of Ecotourism in Tasik Chini: From Exploratory to the Contemporary Biosphere Reserve. Asian Social Science, 9(6), 84-95.

Hansmann, R. (2010). "Sustainability learning": an introduction to the concept and its motivational aspects. Sustainability, 2(9), 2873-2897.

Hearne, R. R., and Santos, C. A. (2005). Tourists 'and locals 'preferences toward ecotourism development in the Maya Biosphere Reserve, Guatemala. Environment, Development and Sustainability, 7(3), 303-318.

Heinrup, M., and Schultz, L. (2017). Swedish Biosphere Reserves as Arenas for Implementing the 2030 Agenda (6742). Swedish Environmental Protection Agency. URL: http://www.divaportal.org/smash/get/diva2:1084701/FULL TEXT01.pdf (Accessed on 15.08.2017)

Hoppstadius, F., and Dahlström, M. (2015). Processes of Sustainable Development: Ecotourism in Biosphere Reserves. 
'You have to try being a role model' - Learning for sustainability among tourism entrepreneurs in a Swedish biosphere reserve.

Journal of Environmental and Tourism Analyses, 3(1), 5-25.

Ishwaran, N., Persic, A., and Tri, N. H. (2008). Concept and practice: the case of UNESCO biosphere reserves. International Journal of Environment and Sustainable Development, 7(2), 118-131.

Kala, C. P., and Maikhuri, R. K. (2011). Mitigating people-park conflicts on resource use through ecotourism: A case of the Nanda Devi Biosphere Reserve, Indian Himalaya. Journal of Mountain Science, 8(1), 87-95.

Kask, S., Kull, T., and Orru, K. (2016). Understanding of sustainable tourism among Russian tourism managers. European Journal of Tourism Research, 14, 101-105.

Keen, M., Brown, V., and Dyball, R. (2005). Social learning: a new approach to environmental management. In M. Keen, V. Brown, and R. Dyball (Eds.) (2005), Social learning in environmental management: towards a sustainable future. London: Routledge, 3-21.

Leach, M., Rokstrom, J., Raskin, P., Scoones, I. C., Stirling, A. C., Smith, A., ... Arond, E. (2012). Transforming innovation for sustainability. Ecology and Society, 17(2), 11.

Leal-Rodríguez, A. L., Roldán, J. L., Leal, A. G., and Ortega-Gutiérrez, J. (2013). Knowledge management, relational learning, and the effectiveness of innovation outcomes. Service Industries Journal, 33(13), 1294-1311. doi:10.1080/02642069.2013.815735

Lundberg, C., Fredman, P., and Wall-Reinius, S. (2014). Going for the green? The role of money among nature-based tourism entrepreneurs. Current Issues in Tourism, 17(4), 373-380.

March, R., and Wilkinson, I. (2009). Conceptual tools for evaluating tourism partnerships. Tourism Management, 30(3), 455-462.

Massey, D. (1991). The political place of locality studies. Environment and Planning A, 23(2), 267-281.

Massey, D. (1995). Spatial divisions of labor: Social structures and the geography of production: Psychology Press.

Massey, D. (2005). For Space. London: SAGE Publications Ltd.
McCarthy, D., Whitelaw, G., Jongerden, P., and Craig, B. (2011). Sustainability, social learning and the long point world biosphere reserve. Environments: a journal of interdisciplinary studies, 34(2).

Mesquita, L. F., Anand, J., and Brush, T. H. (2008). Comparing the resource-based and relational views: Knowledge transfer and spillover in vertical alliances. Strategic Management Journal, 29(9), 913-941. doi:10.1002/smj.699

Möller, C. (2009). Transforming geographies of tourism and gender: exploring women's livelihood strategies and practices within tourism in Latvia. (Doctoral dissertation), Karlstad University, Karlstad.

Morrow, S. L. (2005). Quality and trustworthiness in qualitative research in counseling psychology. Journal of Counseling Psychology, 52(2), 250-260.

Nguyen, N. C., Bosch, O. J. H., and Maani, K. E. (2011). Creating 'learning laboratories' for sustainable development in biospheres: A systems thinking approach. Systems Research and Behavioral Science, 28(1), 51-62.

Ogonowska, M., and Torre, D. (2013). Sustainable tourism and the emergence of new environmental norms. European Journal of Tourism Research, 6(2), 141153.

Paasi, A. (2002). Place and Region: Regional Worlds and Words. Progress in Human Geography, 26, 802-811.

Peet, R. (1998). Modern geographic thought. Oxford: Blackwell Publishers.

Phillimore, J., and Goodson, L. (2004). The inquiry paradigm in qualitative research. In J. Phillimore and L. Goodson (Eds.) (2004), Qualitative research in tourism: Ontologies, epistemologies and methodologies. Ney York: Routledge, 30-46.

Picard, D. (2015). Making ecotourism sustainable: refocusing on economic viability. Lessons learnt from the "Regional strategic action plan for coastal ecotourism development in the South Western Indian Ocean". Journal of Sustainable Tourism, 23(6), 819-837.

Polkinghorne, D. E. (2005). Language and meaning: Data collection in qualitative research. Journal of Counseling Psychology, 52(2), 137 - 145. 
Rakić, T., and Chambers, D. (2012). Rethinking the consumption of places. Annals of Tourism Research, 39(3), 1612-1633.

Regmi, K. D., and Walter, P. G. (2016). Conceptualising host learning in community-based ecotourism homestays. Journal of Ecotourism, 1-13.

Riessman, C. K. (2008). Narrative methods for the human sciences: Sage.

Saarinen, J. (2006). Traditions of sustainability in tourism studies. Annals of Tourism Research, 33(4), 1121-1140.

Sampaio, A. R., Thomas, R., and Font, X. (2012). Why are some engaged and not others? Explaining environmental engagement among small firms in tourism. Journal of Tourism Research, 14(3), 235-249.

Schianetz, K., Kavanagh, L., and Lockington, D. (2007). The learning tourism destination: The potential of a learning organisation approach for improving the sustainability of tourism destinations. Tourism Management, 28(6), 1485-1496.

Smith, D. (1987). The everyday world as problematic. Boston: Northeastern University Press.

Smith, J. K. (1983). Quantitative versus qualitative research: An attempt to clarify the issue. Educational Researcher, 12(3), 613.

Sol, J., Beers, P. J., and Wals, A. E. (2013). Social learning in regional innovation networks: trust, commitment and reframing as emergent properties of interaction. Journal of Cleaner Production, 49(1), 35-43.

Spaargaren, G. (2011). Theories of practices: Agency, technology, and culture: Exploring the relevance of practice theories for the governance of sustainable consumption practices in the new worldorder. Global Environmental Change, 21(3), 813-822.

Stagl, S. (2007). Theoretical foundations of learning processes for sustainable development. The International Journal of Sustainable Development and World Ecology, 14(1), 52-62.

Thomas, K. (2004). The research process as a journey: From positivist traditions into the realm of qualitative inquiry. In J. Phillimore and L. Goodson (Eds.) (2004), Qualitative research in tourism: Ontologies, epistemologies and methodologies. Ney York: Routledge, 197-214.

Thomas, R. (2015). Small firms and sustainable tourism policy. Exploring moral framing. In C. M. Hall and S. Gössling (Eds.) (2015), The Routledge Handbook of Tourism and Sustainability. Abingdon, Oxon: Routledge, 397-426.

UNESCO. (1971). International co-ordinating council of the programme on man and the biosphere (MAB)', First Session. UNESCO-MAB Report Series Paris, France. URL: http://npshistory.com/ publications/mab/unesco-mab-report/1.pdf (Acessed on 20.05.2017)

UNESCO. (1984). Action plan for biosphere reserves. International Coordinating Council of the MAB Programme; 8th session. UNESCO-MAB Report Series Paris, France. URL: http://unesdoc. unesco.org/images/0006/000623/062392 EB.pdf (Accessed on 30.12.2015)

UNESCO. (1996). Biosphere reserves: The Seville strategy and the statutory framework of the World Network. UNESCO-MAB Report Series Paris, France. URL: http://unesdoc.unesco.org /images/0010/001038/103849Eb.pdf (Accessed on 30.12.2015)

UNESCO. (2002). Ecotourism and Sustainable Development in Biosphere Reserves: Experiences and Prospects. UNESCO. Quebec City, Canada. URL: http://unesdoc.unesco.org/images/0012/0 01277/127757e.pdf (Accessed on 16.08.2017)

UNESCO. (2010). MAB Biosphere Reserves Directory - Lake Vänern Archipelago. UNESCO. URL: http://www.unesco.org/ $\mathrm{mabdb} / \mathrm{br} / \mathrm{brdir} /$ directory/biores.asp?mode $=$ allandcode $=\mathrm{SWE}+03 \quad$ (Accessed on 16.07.2016)

UNESCO. (2015). The MAB Strategy 2015 2025. UNESCO. URL: http://www.unesco. org/new/fileadmin/MULTIMEDIA/HQ/SC/p df/MAB_Strategy_2015-2025 final_text. pdf (Accessed on 17.08.2017)

UNESCO. (2016). The Lima Action Plan 2016 2025. UNESCO. URL: http://www.unesco. org/new/fileadmin/MULTIMEDIA/HQ/SC/p df/Lima_Action_Plan en final.pdf (Accessed on $\overline{25} .07 . \overline{2017}$ ) 